Bioorg Med Chem Lett. 2009 September 1; 19(17): 5166-5168. doi:10.1016/j.bmcl.2009.07.062.

\title{
Synthesis of Biotinylated OSW-1
}

\author{
Ying Kang ${ }^{\mathrm{a}}$, Changgang Lou ${ }^{\mathrm{a}}$, Kausar Begam Riaz Ahmed ${ }^{\mathrm{b}}$, Peng Huang ${ }^{\mathrm{b}}$, and Zhendong \\ Jina \\ aDivision of Medicinal and Natural Products Chemistry, College of Pharmacy, The University of \\ lowa, lowa City, IA 52242, USA \\ bDepartment of Molecular Pathology, The University of Texas M.D. Anderson Cancer Center, \\ Houston, TX 77030 USA
}

\begin{abstract}
OSW-1 is a highly potent anticancer natural saponin with an unknown mode of action. To determine its cellular target(s) biotinylated OSW-1 was successfully synthesized in 9 steps.
\end{abstract}

OSW-1, a natural product isolated from the bulbs of Ornithogalum saundersiae, a perennial grown in southern Africa, exhibited extremely potent cytotoxicity against the NCI 60-cell in vitro screen, with a mean $\mathrm{IC}_{50}$ of $0.78 \mathrm{nM}$ (Figure 1). ${ }^{1}$ Its in vitro anticancer activities are from 10 to 1000 times more potent than many well-known anticancer agents in clinical use, including mitomycin $\mathrm{C}$, adriamycin, cisplatin, camptothecin, $5-\mathrm{Fu}$, and even pacilitaxel. ${ }^{2}$ In addition, OSW-1 showed equal potency against cancer cells resistant to other anticancer agents and displayed a characteristic anticancer profile whereas non-malignant cells are significantly less sensitive to OSW-1. ${ }^{3}$ These factors made OSW-1 an attractive synthetic target. ${ }^{4,5}$

The biological study showed that OSW-1 causes cell death by apoptosis and its cell-killing is cycle independent. ${ }^{3}$ It was found that mitochondria play an important role in mediating the anticancer activity in cancer cells, and OSW-1 causes structural damage to the mitochondrial membrane and cristae, leading to the loss of transmembrane potential, a significant increase of cytosolic calcium, and activation of calcium-dependent apoptosis. The biological investigation suggests that OSW-1 may have a novel mechanism of action and represent a new type of drug for cancer chemotherapy. ${ }^{3}$

To determine its molecular target(s) in cells a biotinylated OSW-1 (2) was designed (Figure 2). The biotinylated OSW-1 offers the feature of a reversible solid-support reagent when combined with monomericavidin sepharose or avidin-coated solid surface. ${ }^{6}$ We believe that the C-3 position of the aglycone of OSW-1 should be a suitable place to link biotin. This is because two OSW-1's natural analogs contain a sugar moiety attached to the C-3 position and both analogs have the same potency against cancer cell lines as OSW-1. ${ }^{1}$ Therefore, it is hypothesized that the attachment of the biotin to the $\mathrm{C}-3$ position of the aglycone would not affect the binding of OSW-1 with the receptor.

Our original total synthesis strategy was modified for the synthesis of the biotinylated OSW-1 (2). In our previous total synthesis of OSW-1, the hydroxyl groups in the disaccharide were

\footnotetext{
(C) 2009 Elsevier Ltd. All rights reserved.

Publisher's Disclaimer: This is a PDF file of an unedited manuscript that has been accepted for publication. As a service to our customers we are providing this early version of the manuscript. The manuscript will undergo copyediting, typesetting, and review of the resulting proof before it is published in its final citable form. Please note that during the production process errors may be discovered which could affect the content, and all legal disclaimers that apply to the journal pertain.
} 
protected by PMB groups. ${ }^{5 \mathrm{~b}}$ To avoid possible problems in the oxidative deprotection of PMB groups in the presence of the biotin moiety at the end of the synthesis, we decided to employ the disaccharide with TES protecting groups that was first synthesized by $\mathrm{Yu}$ and his coworkers. ${ }^{5 a}$ The retrosynthetic analysis of the biotinylated OSW-1 (2) is outlined in Scheme 1.

The synthesis of the key fragment $\mathbf{5}$ is outlined in Scheme 2. Compound $\mathbf{8}$, an advanced intermediate in the synthesis of the protected aglycone of OSW-1 in our total synthesis, ${ }^{5 \mathrm{~b}}$ was the point of departure. Deprotection of the TBS group of compound $\mathbf{8}$ by TBAF gave C-3 alcohol 9 in $98 \%$ yield, which reacted with allyl chloroformate to provide carbonate 10 in $84 \%$ yield. Ketone 10 underwent a chemo- and stereo-selective reduction by $\mathrm{LiAlH}_{4}$ at $-78{ }^{\circ} \mathrm{C}$ to provide trans-diol $\mathbf{6}$ in $87 \%$ yield. Glycosylation between the protected aglycone $\mathbf{6}$ and disaccharide donor $\mathbf{7}^{5 \mathrm{a}}$ afforded the compound $\mathbf{1 1}$ in $77 \%$ yield. The allyl carbonate moiety was chemoselectively cleaved under palladium [0] conditions to furnish the requisite fragment 5 in $95 \%$ yield.

The preparation of the linker $\mathbf{4}$ between biotin and OSW-1 is illustrated in Scheme 3. Diol 12 was monomesylated in $70 \%$ yield to give compound 13 , which underwent $\mathrm{S}_{\mathrm{N}} 2$ substitution by sodium azide to afford azide 14 in 94\% yield. PDC-mediated oxidation of alcohol 14 provided linker 4 in $60 \%$ yield.

DCC coupling between alcohol $\mathbf{5}$ and carboxylic acid $\mathbf{4}$ followed by Staudinger reduction of the azide moiety with tri- $n$-butyl phosphine afforded amine 16 in excellent yield (Scheme 4). Amine 16 was coupled with compound 3 to provide fully protected biotinylated OSW-1 17. Treatment of compound $\mathbf{1 7}$ with a catalytic amount of PPTS in methanol for two days resulted in the deprotection of the acetal group and three TES groups and furnished the biotinylated OSW-1 (2) in 98\% yield.

To test if biotinylated OSW-1 (2) has any biological activity, we used MTT assay to evaluate its anti-proliferative effect in several human cancer cell lines. As shown in Figure 3, biotinylated OSW-1 exhibited potent inhibitory activity against human leukemia cells (HL-60), pancreatic cancer cells (Panc1 and AsPC1), and melanoma cells (A375 and WM35). The $\mathrm{IC}_{50}$ values ranged from $0.1 \mathrm{nM}$ to $1.1 \mathrm{nM}$, indicating that this compound is as highly potent in inhibiting cancer cell growth as the parent natural product OSW-1. The biological testing suggests that the attachment of biotin to the $\mathrm{C}-3$ position of the aglycone does not significantly affect the interaction of OSW-1 with its putative target in the cells.

In summary, the biologically active biotinylated OSW-1 has been successfully synthesized from compound $\mathbf{8}$ in 9 steps in very good yield. This synthetic approach can also be used in the preparation of other OSW-1 bioconjugates, which will be very useful in the pharmacological and medicinal investigation of OSW-1. Application of the biotinylatedOSW-1 in the search of OSW-1's cellular target(s) is underway, and will be reported in due course.

\section{Acknowledgement}

This work was supported by a Grant (5R21CA105073-02) from the National Institutes Health.

\section{References and notes}

1. Mimaki Y, Kuroda M, Kameyama A, Sashida Y, Hirano T, Oka K, Maekawa R, Wada T, Sugita K, Beutler JA. Bioorganic Med. Chem. Lett 1997;7:633. and references cited therein. 
2. For the $\mathrm{GI}_{50}$, TGI, and $\mathrm{LC}_{50}$ values of OSW-1 against the NCI 60 cell-line tumor panel, see the Supporting Information of the following reference: Kuroda M, Mimaki Y, Yokosuka A, Sashida Y, Beutler JA. J. Nat. Prod 2001;64:88. [PubMed: 11170674]

3. Zhou Y, Garcia-Prieto C, Carney D, Xu R, Pelicano H, Kang Y, Yu W, Lou C, Kondo S, Liu J, Harris D, Estrov Z, Keating MJ, Jin Z, Huang P. Journal of the National Cancer Institute 2005;97:1781. [PubMed: 16333034]

4. For the synthesis of OSW-1 aglycone, see: a Guo C, Fuchs PL. Tetrahedron Lett 1998;39:1099.; b Guo C, LaCour TG, Fuchs PL. Bioorg. Med. Chem. Lett 1999;9:419. [PubMed: 10091695]; c Morzycki JW, Gryszkiewicz A, Jastrzebska I. Tetrahedron Lett 2000;41:3751.; d Xu Q, Peng X, Tian W. Tetrahedron Lett 2003;44:9375.

5. For the total synthesis of OSW-1, see: a Deng S, Yu B, Lou Y, Hui Y. J. Org. Chem 1999;64:202. [PubMed: 11674104]; b Yu W, Jin Z. J. Am. Chem. Soc 2001;123:3369. [PubMed: 11457074]; c Yu W, Jin Z. J. Am. Chem. Soc 2002;124:6576. [PubMed: 12047177]; d Morzycki JW, Wojtkielewicz A. Carbohydr. Res 2002;337:1269. [PubMed: 12151206]; e Shi B, Tang P, Hu X, Liu JO, Yu B. Jorg. Chem 2005;70:10354.; f Tsubuki M, Matsuo S, Honda T. Tetrahedron Lett 2008;49:229.; f Xue J, Liu P, Pan Y, Guo Z. J. Org. Chem 2008;73:157. [PubMed: 18067313]

6. Sche PP, McKenzie KM, White JD, Austin DJ. Chemistry \& Biology 1999;6:707. [PubMed: 10508685] and references cited therein. 


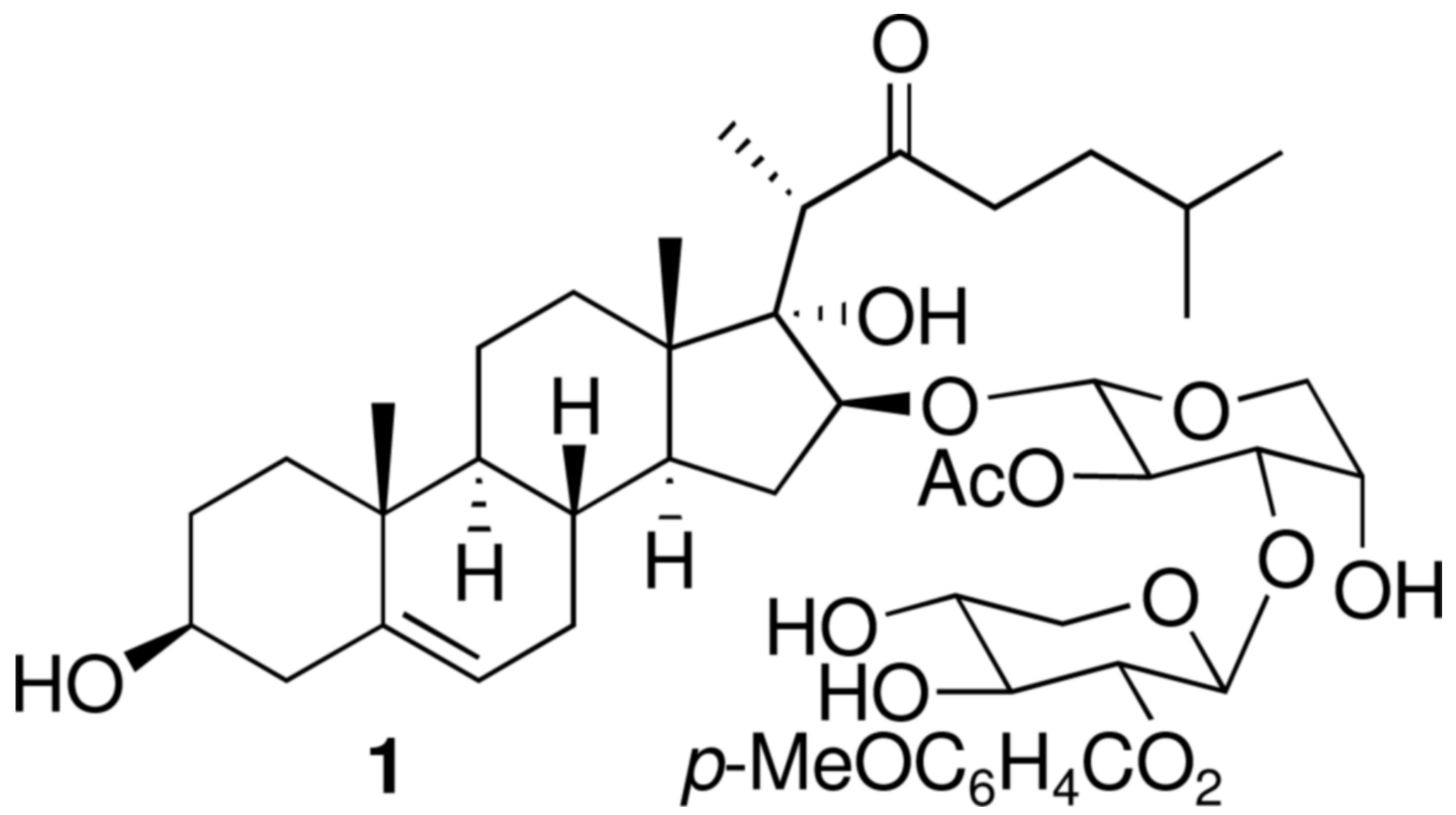

Figure 1.

OSW-1 


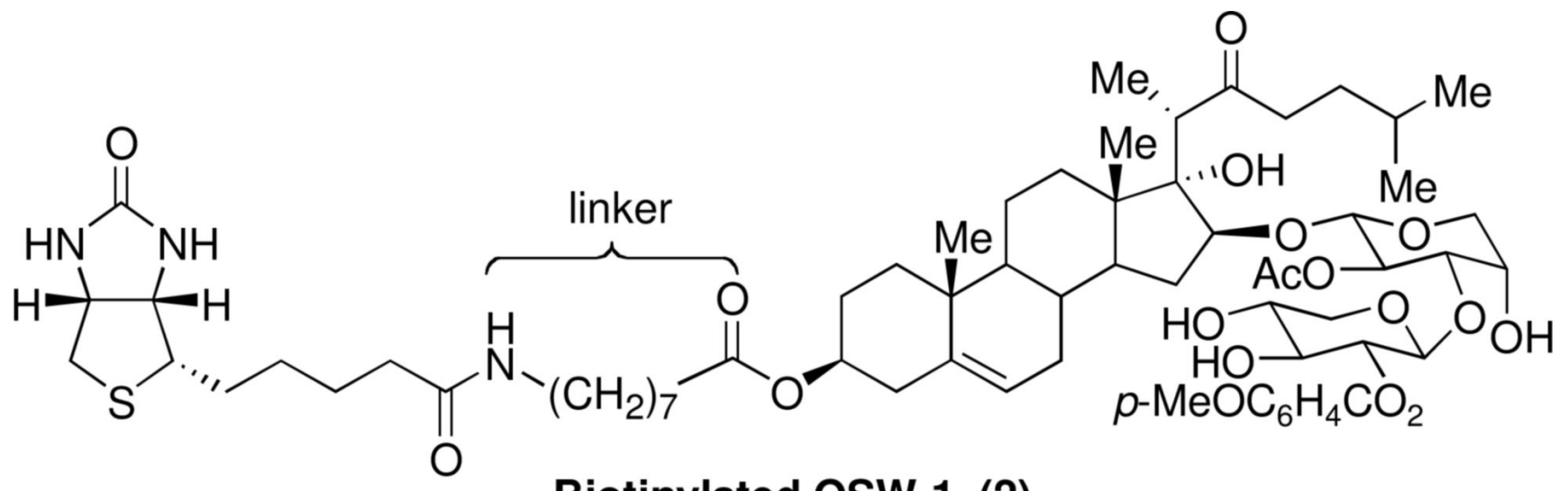

Biotinylated OSW-1 (2)

Figure 2. 
Biotinylated OSW-1 (2)
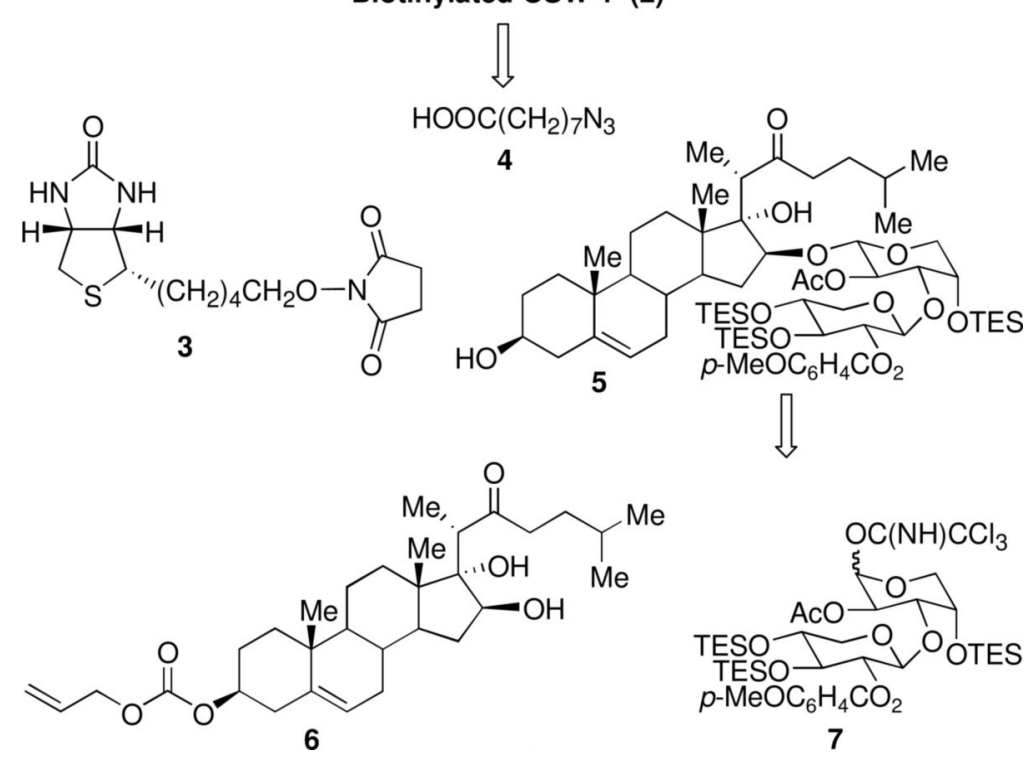

Scheme 1.

Bioorg Med Chem Lett. Author manuscript; available in PMC 2010 September 1. 

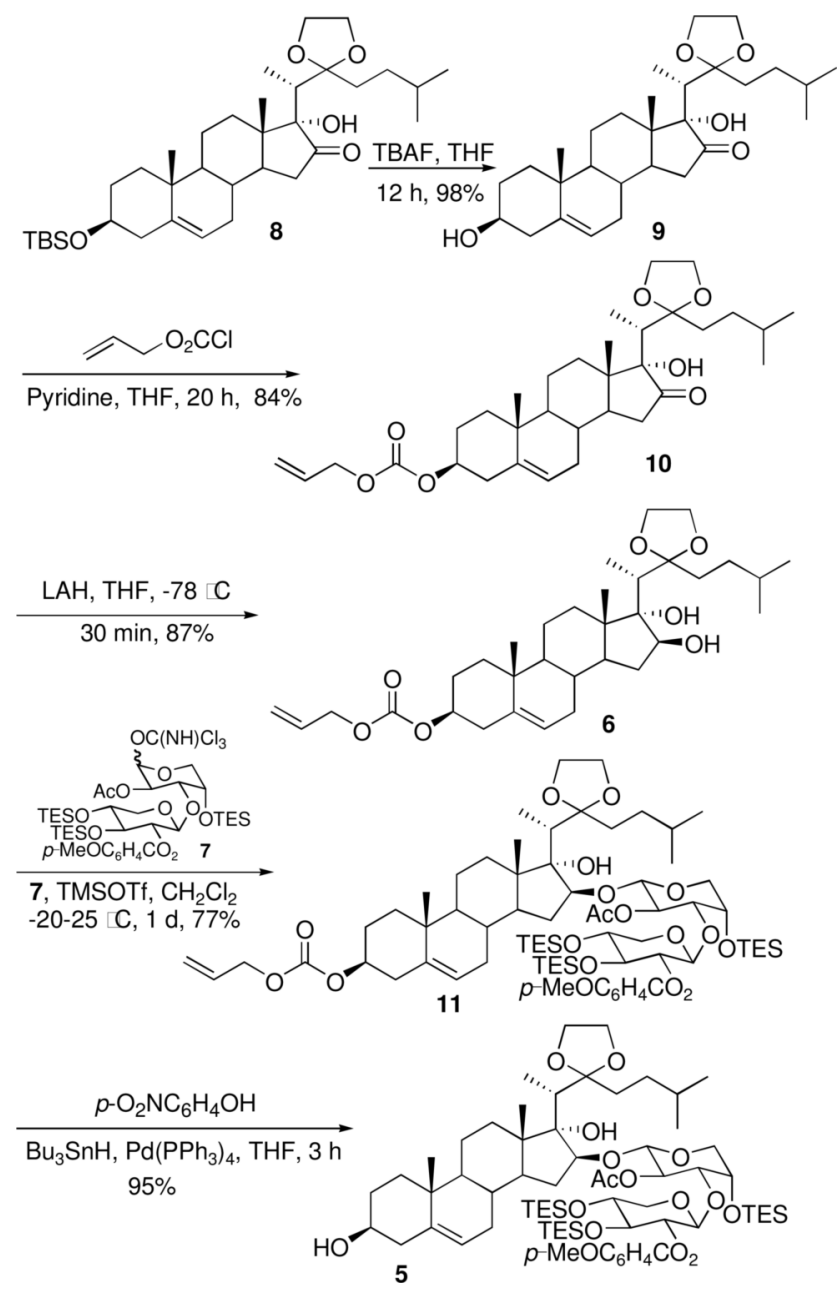

Scheme 2.

Bioorg Med Chem Lett. Author manuscript; available in PMC 2010 September 1. 


$$
\begin{aligned}
& \underset{12}{\mathrm{HO}\left(\mathrm{CH}_{2}\right)_{8} \mathrm{OH}} \stackrel{\mathrm{CH}_{3} \mathrm{SO}_{2} \mathrm{Cl}, \mathrm{NEt}_{3}}{\underset{\mathrm{C}, 5 \mathrm{~h}, 70 \%}{\longrightarrow}} \underset{13}{\mathrm{HO}\left(\mathrm{CH}_{2}\right)_{8} \mathrm{OMs}} \stackrel{\mathrm{NaN}_{3}, \mathrm{DMF}}{\stackrel{\text { reflux, } 5 \mathrm{~h}, 94 \%}{\longrightarrow}} \\
& \underset{14}{\mathrm{HO}\left(\mathrm{CH}_{2}\right)_{8} \mathrm{~N}_{3}} \stackrel{\mathrm{PDC}, \mathrm{DMF}, 2 \mathrm{~d}}{\stackrel{60 \%}{\longrightarrow}} \underset{\mathbf{4}}{\mathrm{HOOC}\left(\mathrm{CH}_{2}\right)_{7} \mathrm{~N}_{3}}
\end{aligned}
$$

Scheme 3 . 


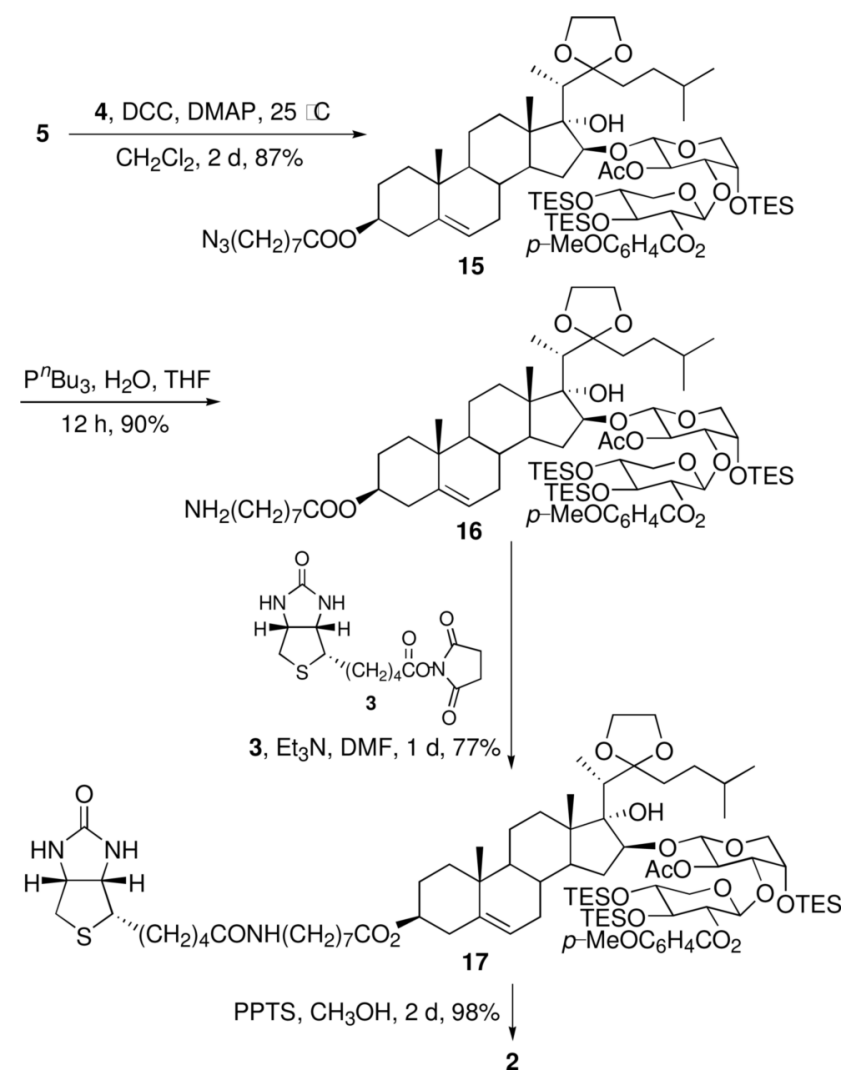

Scheme 4.

Bioorg Med Chem Lett. Author manuscript; available in PMC 2010 September 1. 

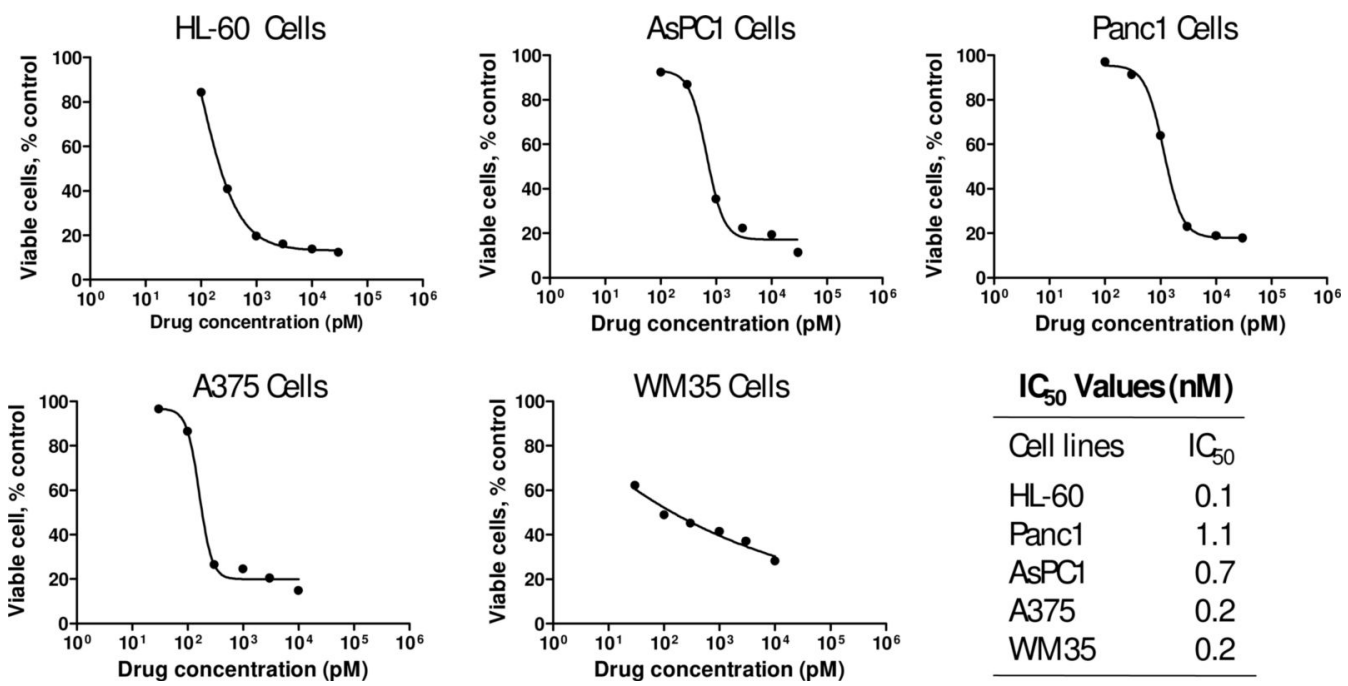

\begin{tabular}{lr}
$\mathbf{I C}_{50}$ Values & $(\mathbf{n M})$ \\
\hline Cell lines & $\mathrm{IC}_{50}$ \\
$\mathrm{HL}-60$ & 0.1 \\
Panc1 & 1.1 \\
AsPC1 & 0.7 \\
A375 & 0.2 \\
WM35 & 0.2 \\
\hline
\end{tabular}

Fig 3.

Human leukemia cells (HL-60), pancreatic cancer cells (Panc1 and AsPC1), and melanoma cells (A375 and WM35) were incubated with the indicated concentrations of biotinylated OSW-1 for 72 h. Cell growth inhibition was measured by MTT assay. Each data point represents the average value of triplicate determinations. 